\title{
Functional Dissection of the Oct6 Schwann Cell Enhancer Reveals an Essential Role for Dimeric Sox10 Binding
}

\author{
Noorjahan B. Jagalur, ${ }^{1,2 \star}$ Mehrnaz Ghazvini, ${ }^{1 \star}$ Wim Mandemakers, ${ }^{1}$ Siska Driegen, ${ }^{1,2}$ Alex Maas, ${ }^{1,2}$ Erin A. Jones, ${ }^{3}$ \\ Martine Jaegle, ${ }^{1,2}$ Frank Grosveld, ${ }^{1,2}$ John Svaren, ${ }^{3}$ and Dies Meijer ${ }^{1,2}$ \\ ${ }^{1}$ Department of Cell Biology and Genetics and 2Netherlands Institute for Regenerative Medicine, Erasmus University Medical Center, 3000 DR Rotterdam, \\ Netherlands, and ${ }^{3}$ Program in Cellular and Molecular Biology, Department of Comparative Biosciences and Waisman Center, University of Wisconsin- \\ Madison, Madison, Wisconsin 53705
}

The POU domain transcription factor Pou3f1 (Oct6/Scip/Tst1) initiates the transition from ensheathing, promyelinating Schwann cells to myelinating cells. Axonal and other extracellular signals regulate Oct6 expression through the Oct6 Schwann cell enhancer (SCE), which is both required and sufficient to drive all aspects of Oct6 expression in Schwann cells. Thus, the Oct6 SCE is pivotal in the gene regulatory network that governs the onset of myelin formation in Schwann cells and provides a link between myelin promoting signaling and activation of a myelinrelated transcriptional network. In this study, we define the relevant cis-acting elements within the SCE and identify the transcription factors that mediate 0ct6 regulation. On the basis of phylogenetic comparisons and functional in vivo assays, we identify a number of highly conserved core elements within the mouse SCE. We show that core element 1 is absolutely required for full enhancer function and that it contains closely spaced inverted binding sites for Sox proteins. For the first time in vivo, the dimeric Sox 10 binding to this element is shown to be essential for enhancer activity, whereas monomeric Sox10 binding is nonfunctional. As Oct6 and Sox10 synergize to activate the expression of the major myelin-related transcription factor Krox20, we propose that Sox10-dependent activation of Oct6 defines a feedforward regulatory module that serves to time and amplify the onset of myelination in the peripheral nervous system.

\section{Introduction}

Within the peripheral nervous system (PNS), Schwann cells generate and maintain a multi-lamellar insulating myelin sheath around an associated axon and impose cellular specializations that allow fast conduction of action potentials. The generation of myelinating Schwann cells from an embryonic pool of precursors and the elaboration of the myelin sheath is primarily controlled by the axons with which the cells associate (Jessen and Mirsky, 2005). Axonal signals that include Neuregulin1, Notch1 ligands, and neurotrophins activate a range of signaling pathways that converge on the nucleus to initiate a program of myelin-related gene transcription (Svaren and Meijer, 2008; Taveggia et al., 2010).

Received Feb. 7, 2011; revised March 10, 2011; accepted March 23, 2011

Author contributions: D.M. designed research; N.B.J., M.G., W.M., S.D., A.M., E.A.J., and M.J. performed research; E.A.J., F.G., and J.S. contributed unpublished reagents/analytic tools; N.B.J., F.G., and D.M. analyzed data; N.B.J. and D.M. wrote the paper.

*N.B.J. and M.G. contributed equally to this work.

This work was supported by grants from the Netherlands Organisation of Scientific Research (VICI Grant 918.66.616, Besluit Subsidies Investeringen Kennisinfrastructuur Program 03038, "Stem Cells in Health and Disease," Aard en Levenswetenschappen Grant 805.17.281, and European Community's Seventh Framework Programme Grant FP7/2007-2013 under Agreement HEALTH-F2-2008-201535) and National Institutes of Health Grant HD41590 (J.S.). We thank Dr. Michael Wegner (University of Erlangen, Erlanger, Germany) for various Sox 10 expression vectors, John Kong A. San for generating transgenic mice, and Drs. Sjaak Philipsen and Elaine Dzierzak for comments on this manuscript.

Correspondence should be addressed to: Dr. Dies N. Meijer, Department of Cell Biology and Genetics, Erasmus University Medical Center, Dr Molewaterplein 50,3015 GE Rotterdam, The Netherlands. E-mail: d.meijer@erasmusmc.nl.

W. Mandemakers present address: Vlaams Instituut voor Biotechnologie, Department of Molecular and Developmental Genetics, Katholieke Universiteit Leuven, 3000 Leuven, Belgium.

DOI:10.1523/JNEUROSCI.0659-11.2011

Copyright $\odot 2011$ the authors $\quad 0270-6474 / 11 / 318585-10 \$ 15.00 / 0$
Several Schwann cell-autonomous regulators of myelination have been identified and studied over the past decades. These include the transcription factors Sox10, Nf $\kappa \mathrm{B}$, Notch, Nfatc4, YY1, Srebp, Oct6, Brn2, and Krox20 (Svaren and Meijer, 2008; Verheijen et al., 2009; He et al., 2010; Taveggia et al., 2010). Perhaps the most intensely studied are the POU-domain transcription factor Oct6 (Pou3f1), the Sry-box protein Sox10, and the zinc finger transcription factor Krox20 (Egr2) (Topilko et al., 1994; Bermingham et al., 1996; Jaegle et al., 1996; Britsch et al., 2001). Whereas Sox10 is expressed at high levels at all stages of the Schwann cell lineage, both Oct6 and Krox20 are expressed dynamically in the Schwann cell lineage during development and nerve regeneration, and their expression is highest in actively myelinating cells (Zorick et al., 1996; Arroyo et al., 1998; Kuhlbrodt et al., 1998; Finzsch et al., 2010). Genetic studies have shown that deletion of Oct6 and its close relative Brn2 (also expressed in the Schwann cell lineage with kinetics similar to that of Oct6) causes severe but transient arrest at the promyelin stage of cell differentiation, resulting in late onset of myelination and hypomyelinated nerves in adult animals (Bermingham et al., 1996; Jaegle et al., 1996, 2003). Deletion of Krox20 similarly results in a differentiation arrest at the promyelin stage, but this arrest is insurmountable (Topilko et al., 1994). Data showing that Oct6/Brn2 cooperate with Sox10 to upregulate Krox20 in myelinating cells through its "myelinating Schwann cell element" suggest a model in which Oct6/Brn2 levels serve to time the onset of myelination in response to promyelinating signals and through activation of Krox20 gene expression (Ghislain and Charnay, 2006; Svaren and Meijer, 2008; Reiprich et al., 2010). Thus, in- 
sight into how Oct6 itself is regulated is pivotal for our understanding of regulation of myelination in the PNS.

We have shown previously that a $4.3 \mathrm{~kb}$ Schwann cell enhancer (SCE) sequence $\sim 10 \mathrm{~kb}$ downstream of the Oct6 transcriptional start site is required and sufficient to drive temporally correct expression from a linked promoter in Schwann cells (Mandemakers et al., 2000; Ghazvini et al., 2002). To begin to understand the nature of the signaling routes that converge on the SCE, we set out to identify the functional elements within the enhancer and identify proteins that bind to these elements.

\section{Materials and Methods}

Computational analysis of the Oct6 Schwann cell enhancer. Conserved elements within the Oct6 SCE of human, mouse, rat, opossum, wallaby, and zebrafish were identified using the VISTA phylogenetic alignment tool (http://pipeline.lbl.gov/cgi-bin/gateway2) (Frazer et al., 2004). All sequences were aligned to the mouse sequence. The homology cutoff standard is $50 \%$ but was adjusted to $90 \%$ for the rat sequence because of the close evolutionary relationship between mouse and rat. Likewise, the homology cutoff was adjusted to $30 \%$ when mouse sequences were aligned to opossum, wallaby, and zebrafish sequences. Alignments were optimized manually. Aligned sequences were further analyzed for the presence of putative transcription factor DNA binding sites using ConSite, a Web-based tool for finding cis-regulatory elements in genomic sequences (Sandelin et al., 2004) (http:// www.phylofoot.org/consite).

Cell culture, transient transfection, and nuclear extract preparation. Primary rat Schwann cell cultures were established as described previously (Brockes et al., 1979; Mandemakers et al., 2000). Rat Schwann cells were maintained in DMEM (Lonza), 3\% fetal calf serum (FCS) (Harlan), $2 \mu \mathrm{M}$ Forskolin (Sigma), 1\% penicillin and streptomycin (PS) (Invitrogen), and $5 \%$ Neu differentiation factor- $\beta$ (NDF- $\beta$ ) conditioned medium (Spiegel and Peles, 2009) at $37^{\circ} \mathrm{C}$ with $5 \% \mathrm{CO}_{2}$. Schwann cells were differentiated in vitro toward an early myelinating stage (Morgan et al., 1991), a stage at which they express relatively high levels of Oct6. First, medium was switched to a serum-free formulation of DMEM/F-12 (Lonza), $1 \times \mathrm{N} 2$ supplement (Invitrogen), $10 \mathrm{ng} / \mathrm{ml}$ NGF (Harlan), $0.01 \%$ BSA (Invitrogen), $5 \%$ NDF- $\beta$ conditioned medium, and $1 \%$ PS for $18 \mathrm{~h}$. Cells acquire a spindle-shaped form under serum-free conditions. Then, differentiation was initiated by addition of $20 \mu \mathrm{M}$ Forskolin (Sigma) or $100 \mu \mathrm{M}$ CTP-cAMP (Sigma). Cells were allowed to differentiate for $36 \mathrm{~h}$ before additional analysis. Differentiated cells have flattened cell morphology and express high levels of Oct6.

RT4-D6P2T rat Schwannoma cells (Bansal and Pfeiffer, 1987; Gandelman et al., 1989) were obtained from the European Collection of Cell Cultures and were maintained in DMEM, 10\% FCS, and 1\% PS. For nuclear extract preparation, RT4-D6P2T cells were grown in $15 \mathrm{~cm}$ dishes to near confluence. When confluent, cells were washed once with PBS and scraped in cold PBS, and nuclear extracts were prepared essentially according to Dignam et al. (1983). Nuclei were extracted in $20 \mathrm{~mm}$ HEPES-KOH, pH 7.6, 25\% glycerol, $420 \mathrm{~mm} \mathrm{NaCl}, 1.5 \mathrm{~mm} \mathrm{MgCl}_{2}, 0.2$ mм EDTA, $0.5 \%$ NP-40, $0.5 \mathrm{~mm}$ DTT, and $1 \times$ complete protease inhibitor mix (Roche). The salt concentration of the extract was reduced by dialysis against a buffer containing $20 \mathrm{~mm}$ HEPES-KOH, pH7.6, 25\% glycerol, $100 \mathrm{~mm} \mathrm{KCl,} 1.5 \mathrm{~mm} \mathrm{MgCl}_{2}, 0.2 \mathrm{~mm}$ EDTA, $0.5 \mathrm{~mm}$ DTT, 0.2 mM phenylmethylsulfonyl fluoride, and $95 \mu \mathrm{g} / \mathrm{ml}$ sodium metabisulfite. Precipitates were removed by centrifugation two times at $13,000 \mathrm{rpm}$ for $15 \mathrm{~min}$, at $4^{\circ} \mathrm{C}$. The dialyzed nuclear extract was snap frozen and stored in aliquots at $-80^{\circ} \mathrm{C}$.

HEK293T cells were maintained in DMEM, 10\% FCS, and 1\% PS. HEK293T cells were transfected with $20 \mu \mathrm{g}$ of pCMV promoter-driven full-length Sox10 or MIC Sox10 (kind gift from Prof. Michael Wegner, University of Erlangen, Erlanger, Germany) expression cassettes in $10 \mathrm{~cm}$ dishes using the polyethylenimine method. Cells were harvested $48 \mathrm{~h}$ after transfection for nuclear extract preparation (Jaegle et al., 2003).

Luciferase assay. Rat Schwann cells were seeded in six-well Primaria dishes (BD Biosciences) and grown to $70-80 \%$ confluence. Cells were transfected in triplicate with $1.125 \mu \mathrm{g}$ of pGL3 luciferase reporter plasmid (Promega) containing different SCE fragments and $0.375 \mu \mathrm{g}$ of
pCMV- $\beta$-galactosidase reference expression plasmid in the presence of FCS, using FUGENE6 transfection reagent (Roche) at a 1:4 (DNA/ FUGENE6) ratio. Cells were washed $18 \mathrm{~h}$ after transfection, and medium was switched to a serum-free formulation [DMEM/F-12 (Lonza), $1 \times \mathrm{N} 2$ supplement (Invitrogen), $10 \mathrm{ng} / \mathrm{ml}$ NGF (Harlan), 0.01\% BSA (Invitrogen), $5 \%$ NDF- $\beta$ conditioned medium, and $1 \%$ PS]. After overnight incubation in this medium, cells were induced to differentiate through addition of CTP-cAMP to a final concentration of $100 \mu \mathrm{M}$ and cultured for an additional $36 \mathrm{~h}$. Cells were harvested $72 \mathrm{~h}$ after transfection, washed, and lysed in $1 \times$ lysis buffer (Promega), and extracts were assayed for luciferase activity using Steady GLO luciferase substrate buffer (Promega) and $\beta$-galactosidase activity using 2-nitro-phenyl-galacto-pyranoside substrate. Luciferase activities were normalized for $\beta$-galactosidase activity. Both luciferase and $\beta$-galactosidase levels were measured on a luminometer (Victor3; PerkinElmer Life and Analytical Sciences). All the experiments were performed at least three times in triplicate.

DNA cloning and SCE deletion constructs. The mouse SCE was originally cloned as an HpaI-MscI DNA fragment from a mouse 129sv cosmid library (Mandemakers et al., 2000). This fragment, which corresponds to position $124,342,041-124,349,427$ on mouse chromosome 4 of genome build37 (NCBIM37), was used to generate, by PCR, a series of 10 deletion constructs in which a shifting window of $\sim 500 \mathrm{bp}$ is deleted from the entire SCE. SalI and BglII restriction sites were introduced at the $5^{\prime}$ and $3^{\prime}$ ends, respectively, and these sites were used to clone the fragments into the SV40 promotordriven pGL3 luciferase reporter plasmid. Subfragments from the SCE such as HR1a and HR2 were generated by PCR using the HpaI-MscI SCE fragment as template and cloned into luciferase and LacZ reporter plasmids (Mandemakers et al., 2000). Fragment HR1a corresponds to position 124,344,894$124,345,418$ and HR2 to position $124,347,550-124,348,429$ on mouse chromosome 4 (NCBIM37).

Transgenic mice and whole-mount $\beta$-galactosidase staining. Transgenesis and identification of transgenic embryos by PCR and Southern blotting was performed as described previously (Mandemakers et al., 2000). LacZ expression was visualized by whole-mount 5-bromo-4-chloro-3indolyl- $\beta$-D-galactopyranoside (X-gal) staining of $\mathrm{P} 2-\mathrm{P} 4$ pups or nerves dissected from transgenic animals at different stages of postnatal development. In brief, young mice (2-4 d of age and of either sex) were anesthetized and killed by decapitation. The body cavity was opened and the major organs were removed. All of the tissue was transferred to a solution of fixative containing $1 \%$ formaldehyde, $0.2 \%$ glutaraldehyde, 2 mM $\mathrm{MgCl}_{2}, 5 \mathrm{~mm}$ EGTA, and $0.02 \% \mathrm{NP}-40$ in PBS, for $1 \mathrm{~h}$ at room temperature (RT). Tissues were washed in PBS/0.02\% NP-40 for three times at RT. $\beta$-Galactosidase staining was performed overnight at RT in staining solution containing $5 \mathrm{~mm} \mathrm{~K}_{3} \mathrm{Fe}(\mathrm{CN})_{6}, 5 \mathrm{~mm} \mathrm{~K}_{4} \mathrm{Fe}(\mathrm{CN})_{6} .3 \mathrm{H}_{2} 0,2$ $\mathrm{mM} \mathrm{MgCl}_{2}, 0.01 \%$ sodium deoxycholate, $0.02 \% \mathrm{NP}-40$, and $1 \mathrm{mg} / \mathrm{ml}$ $\mathrm{X}$-gal. The staining was stopped by extensively washing in $\mathrm{PBS} / 0.02 \%$ NP-40 and postfixed in a $4 \%$ formaldehyde fixative.

All animal experiments were performed according to guidelines and protocols that had been approved by an independent committee on the ethical use of experimental animals (Dier Experimenten Commissie).

Electrophoretic mobility shift assay. Equal amounts of nuclear extract were used in the electrophoretic mobility shift assay (EMSA) using 50 fmol of a ${ }^{32} \mathrm{P}$ end-labeled double-strand oligonucleotide probe. Probe and nuclear extracts were incubated on ice, for $30 \mathrm{~min}$ in $10 \mathrm{mM} \mathrm{HEPES}-$ $\mathrm{KOH}, \mathrm{pH}$ 7.9, $100 \mathrm{~mm} \mathrm{KCl}, 5 \mathrm{~mm} \mathrm{MgCl}$, 0.1\% EDTA, 2 mм DTT, $4 \mu \mathrm{g}$ of BSA, and $4 \%$ Ficoll in the presence of $2 \mu \mathrm{g}$ of competitor DNA, poly (dG-dC) (Sigma). Total reaction volume was $20 \mu \mathrm{l}$. In super shift experiments, reaction mixtures were further incubated for $20 \mathrm{~min}$ with 1 $\mu \mathrm{g}$ of goat Sox10 antibody (Santa Cruz Biotechnology). Complexed and free probe were separated on a $4 \%$ polyacrylamide gel, which was pre-run for $30 \mathrm{~min}$ at $120 \mathrm{~V}$ in $0.5 \times$ Tris-borate-EDTA electrophoresis buffer at RT. Gels were fixed in 10\% methanol/10\% acetic acid for 20 min, dried, and exposed to a phospho-imaging screen (Molecular Dynamics). NIH ImageJ software was used to analyze the band intensities. Probes used in the band shift assays are shown in Figure 5.

Chromatin immunoprecipitations. For chromatin immunoprecipitation (ChIP) assays in RT4-D6P2T cells $\left(20 \times 10^{6}\right.$ cells per immunoprecipitation), dual crosslinking was performed using $\operatorname{di}(N$-succimidyl $)$ glutarate (DSG) and formaldehyde (van den Berg et al., 2008). Cells were washed four 

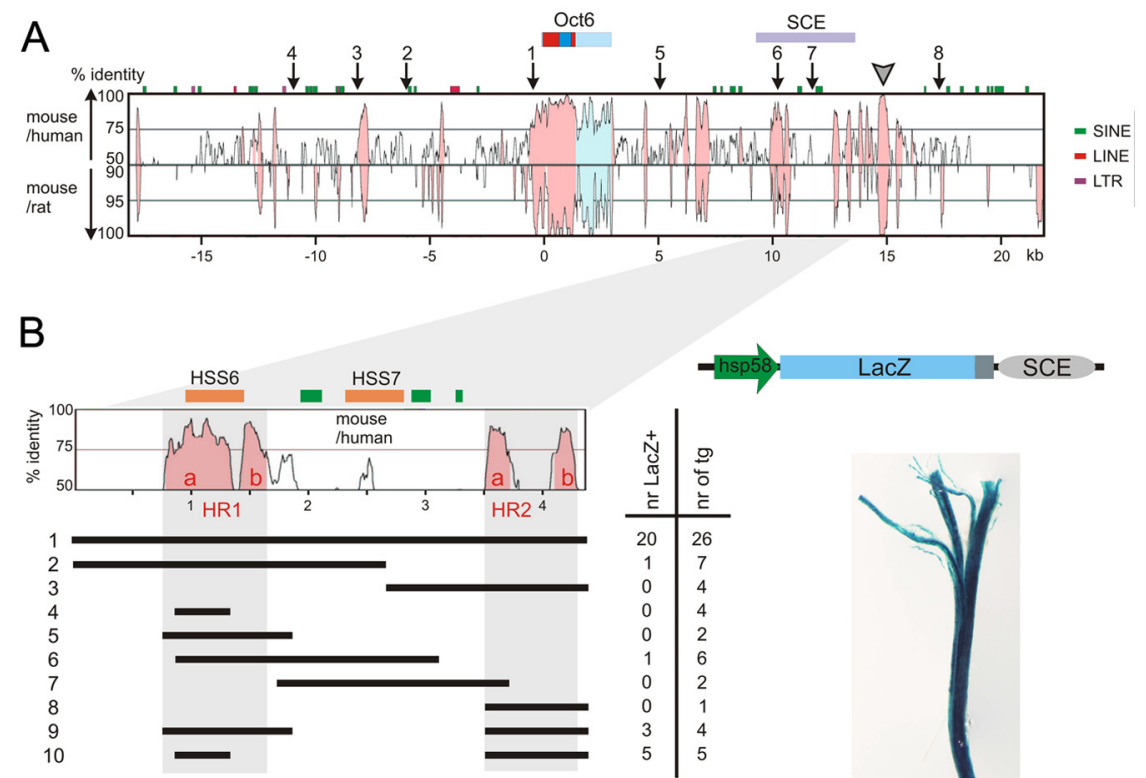

C

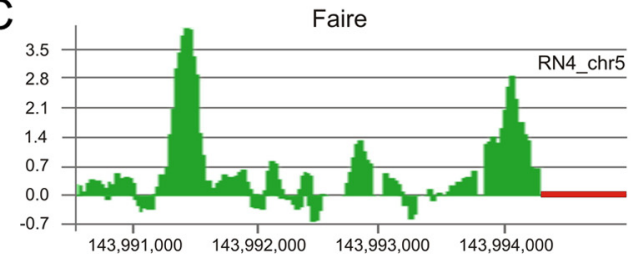

Figure 1. Comparative genomic and functional analysis of the mouse 0ct6 locus. $A$, VISTA alignment of the mouse, rat, and human $0 c t 6$ locus spanning $\sim 50 \mathrm{~kb}$. The position of the $0 \mathrm{ct} 6$ transcription unit and the SCE are indicated above the plot. The $0 \mathrm{ct} 6$ open reading frame is in red, with the POU domain in dark blue and the $3^{\prime}$ untranslated region in light blue. The gray arrowhead marks the position of the ultraconserved sequence, and numbered arrows mark the position of the previously mapped DNasel hypersensitive sites (Mandemakers et al., 2000). Repeat sequences present in the mouse genome are indicated. SINE, Short interspersed elements; LINE, long interspersed elements; LTR, long terminal repeat. Note that the homology threshold has been adjusted to $90 \%$ for the rat sequence. $\boldsymbol{B}$, The enlarged section of the SCE region shows the four regions of strong homology, HR1a, HR1b, HR2a, and HR2b, between mouse and human sequences. The approximate position of HSS6 and HSS7 as well as the short repeat sequences (in green) are indicated. The black lines represent the segments of the SCE that were cloned behind the Hsp68LacZ reporter construct. Individual constructs were tested for activity in transgenic mice, and the number of transgenic founders ( $\mathrm{nr}$ of tg) and those that express the Hsp68LacZ in the peripheral nerves $\left(\mathrm{nr} \mathrm{LaCZ}{ }^{+}\right)$are indicated. A dissected sciatic nerve of a P2 mouse transgenic for construct 9 is shown as a typical example. C, The FAIRE plot of the rat 0ct6 SCE is shown at the same scale as the VISTA plot in $\boldsymbol{B}$ to allow a direct visual comparison of the two plots. The coordinates of the rat genome sequence (RN4) are indicated. The red bar indicates sequences not represented on the custom-made microarray used in this experiment.

times with PBS, followed by incubating the cells with crosslinking agent, 2 $\mathrm{mm}$ DSG, on a rotating platform at a medium speed for $45 \mathrm{~min}$ at RT. After washing the cells four times with PBS, conventional formaldehyde crosslinking was performed by incubating the cells in freshly prepared buffered formaldehyde (50 mм HEPES-KOH, pH 7.5, 100 mm Nacl, 1 mm EDTA, 0.5 mm EGTA, and $1 \%$ formaldehyde) for $10 \mathrm{~min}$. Glycine at $2.5 \mathrm{~m}$ was added to a final concentration of $100 \mathrm{~mm}$ to quench the formaldehyde, and cells were further incubated for $5 \mathrm{~min}$ at RT. From here on, all the subsequent steps were performed at $4^{\circ} \mathrm{C}$ in the presence of complete EDTA free protease inhibitor (Roche). Cells were scraped in cold PBS and spun at $2000 \mathrm{rpm}$ for 5 min. Cell pellet was resuspended in SDS lysis buffer (1\% SDS, $10 \mathrm{~mm}$ EDTA, and $50 \mathrm{~mm}$ Tris, $\mathrm{pH} \mathrm{8.0)}$ and subsequently sonicated for 15 cycles with 15-s on and 30-s off regimen. The sheared chromatin was cleared of insoluble debris by centrifugation at 13,000 rpm for $10 \mathrm{~min}$. The supernatant containing the sheared chromatin was precleared with protein A Agarose/ Salmon sperm DNA (Millipore) for $1 \mathrm{~h}$ at $4^{\circ} \mathrm{C}$. Chromatin at $1 \%$ was set aside to serve as a $1 / 100$ of total chromatin input control. After centrifugation, the supernatant was incubated with $10 \mu \mathrm{g}$ of anti-Sox10 antibody (Abcam) or $10 \mu \mathrm{g}$ of normal rabbit IgG (Santa Cruz Biotechnology) control antibody at $4^{\circ} \mathrm{C}$ on a rotating wheel overnight. Immune complexes were incubated with $60 \mu$ l of protein A Agarose/Salmon sperm DNA slurry for $1 \mathrm{~h}$ at $4^{\circ} \mathrm{C}$. After centrifugation, the immune complexes were washed once with $1 \mathrm{ml}$ of low-salt buffer $(0.1 \%$ SDS, $1 \%$ Triton X-100, 2 mu EDTA, 20 mm Tris-HCl, pH 8.0, and $150 \mathrm{~mm}$ $\mathrm{NaCl})$, once with high-salt buffer $(0.1 \%$ SDS, $1 \%$ Triton X-100, 2 mм EDTA, 20 mm Tris-HCl, pH 8.0 , and $500 \mathrm{~mm} \mathrm{NaCl}$ ), once with lithium chloride wash buffer $[0.25 \mathrm{M} \mathrm{LiCl}, 1 \% \mathrm{NP}-40,1 \%$ deoxycholic acid(sodium salt), $1 \mathrm{~mm}$ EDTA, and 10 mM Tris, $\mathrm{pH} 8.0$ ], and twice with TE buffer (10 mM Tris, pH 8.0, 1 mm EDTA) (all the wash buffers contain protease inhibitor). Immunoprecipitated chromatin was eluted twice each time with $250 \mu \mathrm{l}$ of elution buffer ( $1 \%$ SDS, $0.1 \mathrm{M}$ $\mathrm{NaHCO}_{3}$ ). The elutions were pooled, and $5 \mathrm{~m}$ $\mathrm{NaCl}$ was added to a final concentration of 300 mM. Furthermore, crosslinks were reversed by incubating the sample at $65^{\circ} \mathrm{C}$ for $5 \mathrm{~h}$. The solution was adjusted to $10 \mathrm{~mm}$ EDTA and $10 \mathrm{~mm}$ Tris$\mathrm{HCl}, \mathrm{pH}$ 6.5. Proteinase $\mathrm{K}(10 \mathrm{mg} / \mathrm{ml})$ was added to $40 \mu \mathrm{g} / \mathrm{ml}$, and the solution was incubated for $1 \mathrm{~h}$ at $45^{\circ} \mathrm{C}$. DNA was purified with phenol/ chloroform/isoamyl alcohol, precipitated with $\mathrm{EtOH}$, and dissolved in water. The same reverse crosslinking and purification procedure was followed for the input sample. Comparative cycle threshold values (Livak and Schmittgen, 2001) were used to calculate the enrichment of a DNA segment relative to the total input. These values were used to calculate the relative enrichment of Sox10 antibody over rabbit IgG precipitated chromatin for the core $1(\mathrm{c} 1),-13 \mathrm{~kb}$, and IgG2a promoter regions. Primer sets used in quantitative PCR for ChIP are as follows: $\mathrm{cl}$ of SCE, 5'-GCC CTG AGG ACT CTA GCT CT-3' and 5'-GCA GGA CAA TAG CTG CAT TC-3'; $-13 \mathrm{~kb}, 5^{\prime}$-AAT CAC GTC CTC ACC AAA CC- $3^{\prime}$ and $5^{\prime}$-TCC GGT TAG CTC GAA TCC TA-3'; and IgG2aP, 5'-GAA ATT CTG CCC TGC ACT TCC- $3^{\prime}$ and $5^{\prime}$-GCT TTG CAT TGA GGG AGG ATC-3'.

In vivo formaldehyde-assisted identification of regulatory elements. Freshly isolated $\mathrm{P} 14$ rat sciatic nerves were minced in PBS with $1 \%$ formaldehyde for $5 \mathrm{~min}$ at RT. The nerves were washed with cold PBS and frozen at $-80^{\circ} \mathrm{C}$. After thawing, the nerves were analyzed by formaldehyde-assisted identification of regulatory elements (FAIRE) as described previously (Giresi and Lieb, 2009; Jang et al., 2010). A custom microarray (Roche NimbleGen) consisting of $50 \mathrm{~kb}$ Oct6 rat gene locus was used for identification of regions enriched by FAIRE. Labeling of the FAIRE with Cy5 and total input with Cy3 followed by microarray hybridization was performed as described previously (Jang and Svaren, 2009) by Roche NimbleGen. The enrichment ratio of $\mathrm{Cy} 5$ to $\mathrm{Cy} 3$ was plotted on a $\log _{2}$ scale and further processed to display a moving average using a window size of five probes. All raw datasets for the custom tiled array are available from the NCBI Gene Expression Omnibus website (http://www.ncbi.nlm.nih.gov/geo/; accession number GSE23648).

\section{Results}

\section{The Oct6 SCE contains two functionally interdependent conserved modules}

Previously, DNaseI hypersensitivity mapping and alignment of the genomes of human, mouse, and rat using the VISTA alignment tool presented here, localized several possible Oct6 regulatory regions including the SCE (Fig. 1A). Among the strongly conserved regions within the Oct6 locus, only three regions (at $-8,-0.5$, and $+10.5 \mathrm{~kb}$ ) correspond with previously identified 
3DNaseI hypersensitive sites (HSS) (Fig. $1 A$, numbered arrows). The conserved peak at $-4.8 \mathrm{~kb}$ corresponds with an estradiol-responsive enhancer characterized by Renner et al. (1996). The large conserved region containing the Oct6 gene contains the promoter proximal region at $-0.5 \mathrm{~kb}$, which confers interferon- $\beta$ responsiveness and is important for the regulated expression of Oct6 in macrophages (Hofmann et al., 2010). An ultraconserved element flanks the $3^{\prime}$ end of the locus (Fig. $1 A$, arrowhead) at approximately $+15 \mathrm{~kb}$ (Bejerano et al., 2004) and is downstream of the SCE. All of these elements are dispensable for Oct6 expression in vivo in the Schwann cell lineage. The relevance of the other conserved elements, outside the boundaries of the SCE, for the regulated expression of Oct6 in cells other than Schwann cells is not known.

Within the defined boundaries of the SCE, there are two pairs of conserved elements, which we termed HR1a and HR1b (at +10 to $10.8 \mathrm{~kb}$ ) and HR2a and HR2b (at +13 to $13.7 \mathrm{~kb}$ ). The HR1 region corresponds to DNaseI HSS6, whereas HSS7 maps to a marginally conserved region between HR1 and HR2. To test the relative contributions of conserved elements within the enhancer to Schwann-cellspecific expression in transgenic mice, we generated a number of constructs that were linked to the generic minimal promoter of the Hsp68 gene driving expression of the LacZ gene (Fig. 1B). These constructs were analyzed for Schwanncell-specific expression of the LacZ reporter in the sciatic nerve of $\mathrm{F}_{0}$ transgenic animals at postnatal day $2-4$ by wholemount X-gal staining. The blue sciatic nerve in Figure $1 B$ is a typical example of such analysis. Confirming our previous results (Mandemakers et al., 2000), the full 4.3 $\mathrm{kb}$ SCE construct confers Schwann-cell-specific expression in transgenic animals with high frequency (construct 1; 20 of 26 transgenic animals) (Fig. $1 B$ ), whereas the 5 ' region (construct 2; one of seven) and 3' region (construct 3; zero of four) alone did not drive expression in Schwann cells at an appreciable frequency. However, these constructs abutted in the HSS7 region, leaving open the possibility that in both these constructs essential genetic information was disrupted. To examine this possibility, five constructs (constructs 4-8) spanning the width of the SCE were generated. Only one (construct 6) of these constructs conferred Schwann cell expression on the Hsp68 promoter in transgenic mice, although again at a low frequency (one of six transgenic animals). We then combined DNA fragments covering HR1 or HR1a and HR2 in one construct (constructs 9 and 10, respectively) and found that both fragments are required to confer high frequency of reporter gene expression in Schwann cells of transgenic mice. Furthermore, these data show that HR1 can be reduced to HR1a without loss of activity.

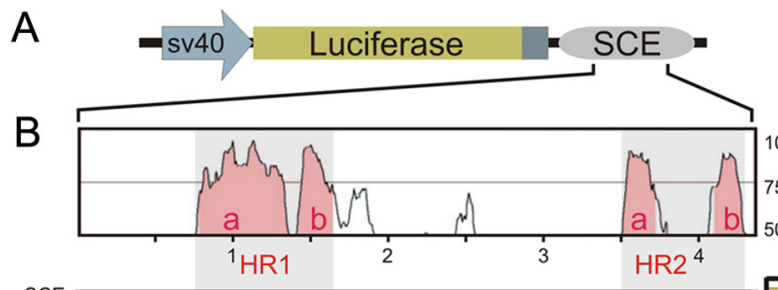

\section{Luciferase activity} $100 \% \quad 200 \%$

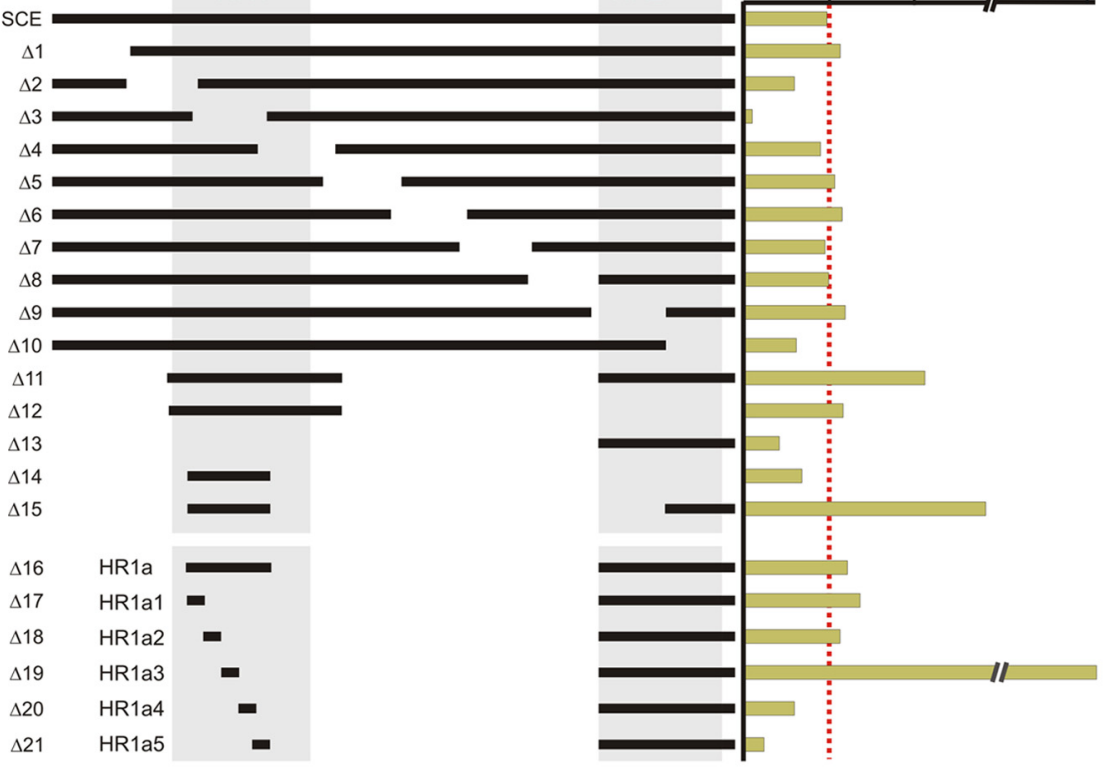

C

Figure 2. Dissection of 0ct6 SCE functional elements in differentiating Schwann cell cultures. A, SCE constructs were cloned behind the minimal SV40 promoter-driven luciferase cassette (pGL3) and transfected in rat Schwann cells. $\boldsymbol{B}$, The SCE constructs are represented with a black line and aligned with the VISTA plot. Luciferase activity of each construct is expressed as a HR1a3, which has strong enhancer activity in the luciferase assay, shows potential binding sites for transcription factors known to be involved in Schwann cell biology. These potential binding sequences were identified using the phylogenetic footprinting program ConSite. The sequence of the $c 2$ element, containing the consensus Sox binding site, is underlined.

Active enhancer elements are associated with a relatively open chromatin configuration, devoid of nucleosomes, and these can be probed using FAIRE (Giresi et al., 2007). Using this assay on chromatin derived from 2-week-old rat sciatic nerve, strong peaks at both HR1a and HR2 were found, in line with our functional transgenic expression results. Thus, both regions are associated with a relatively open chromatin structure and are interdependently required for formation of an active enhancer in Schwann cells.

\section{Deletion analysis of the SCE in cultured Schwann cells}

To more finely delineate the essential elements within the Schwann cell enhancer, an in vitro rat Schwann cell culture system was used, because it is rapid and inexpensive compared with transgenic mouse experimentation. Primary rat Schwann cells can be cultured indefinitely (Brockes et al., 1979; Mathon et al., 2001) and, when exposed to agents that elevate intracellular cAMP levels, can be induced to differentiate into a cell that resembles an early myelinating Schwann cell. Under these conditions, endogenous Oct6 expression is induced within $3 \mathrm{~h}$, reaching maximum levels after $24 \mathrm{~h}$ (Monuki et al., 1989). We generated a series of deletion constructs $(\Delta 1$ to $\Delta 10)$ covering the 


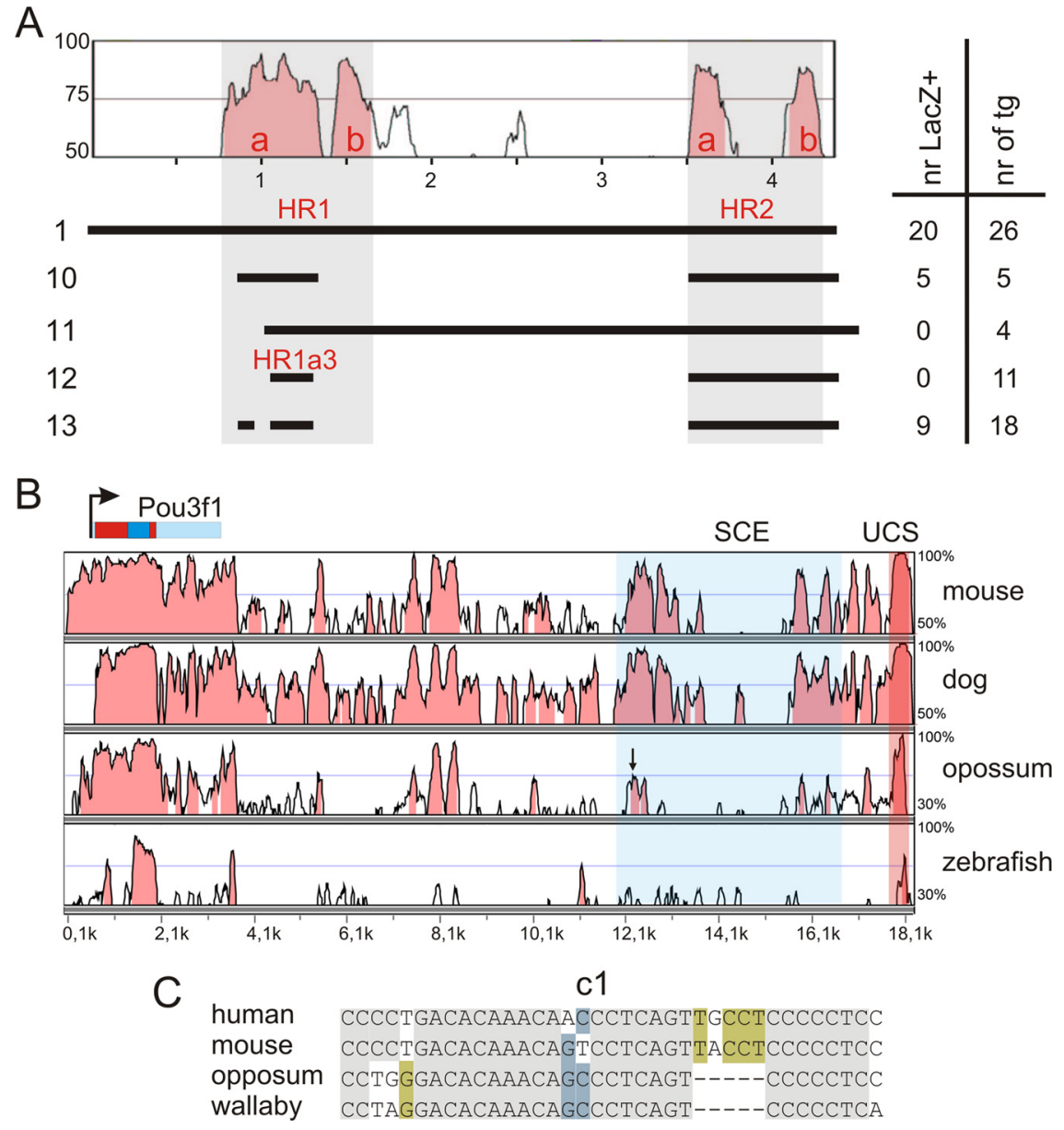

Figure 3. Functional analysis of SCE elements in transgenic mice and comparative genomics. $A$, Schematic depiction of the SCE constructs tested in transgenic mice. The SCE constructs are represented by black lines aligned with the VISTA plot of the mouse SCE to visualize the presence or absence of conserved sequences in the various constructs. The total number of transgenic animals ( $\mathrm{nr}$ of $\mathrm{tg}$ ) and the number of animals that express the transgene in neonatal peripheral nerves ( $\left.\mathrm{nrLacZ}{ }^{+}\right)$is indicated. All animals were analyzed as founders. B, VISTA alignment of human SCE sequence with mouse, dog (Canis familiaris), opossum (Monodelphis domestica), and zebrafish (Danio rerio). Note that the lower homology threshold has been set to $30 \%$ for opossum and zebrafish to allow for the visualization of more diverged homologous regions. The position of core element $\mathrm{c} 1$ in the VISTA plot of opossum is indicated by an arrow. UCS, Ultra-conserved sequence. C, Alignment of core element c 1 in the SCE of human, mouse, opossum, and wallaby (Macropus eugenii). Hundred percent homologous nucleotides are boxed in black, $75 \%$ homology in light blue, and $50 \%$ homology in ochre.

entire SCE (and cloned these in an SV40 promoter-driven luciferase vector) (Fig. $2 A, B)$. These constructs were cotransfected with a CMV promoter-driven $\beta$-galactosidase reference reporter into rat Schwann cells. Cells were cultured for $18 \mathrm{~h}$ in serum-free medium, switched to differentiation medium for another $36 \mathrm{~h}$, and measured for luciferase and $\beta$-galactosidase activity. All luciferase values were normalized for $\beta$-galactosidase activity. The activity of the entire enhancer was set to $100 \%$ (Fig. $2 B$ ), and activity of the various SCE deletions is reported as percentage of the full SCE activity. From this deletion screen, it is evident that a major enhancing activity is associated with the region covered by $\Delta 3$ and, to lesser extent, $\Delta 2$ and $\Delta 10$. These regions coincide with the HR1 and HR2 conserved regions.

Next we tested whether the HR1 and HR2 regions, alone or in combination, would enhance gene expression in transfected Schwann cells (Fig. $2 B$ ) (constructs $\Delta 11-\Delta 13$ ). In contrast with our transgenic data, we found that HR1 $(\Delta 12)$ is as active as the full enhancer, although this activity is further enhanced by the presence of HR2 (as in $\Delta 11$ ). HR2 by itself is less active than the full enhancer.
Additional restriction of HR1 to HRla as in constructs $\Delta 14$ and $\Delta 15$ suggested that the major enhancer activity of HR1 is located within HRla, but that this activity is boosted by the presence of HR2 sequences.

To identify the major functional elements within the HRla region, we tested a series of smaller overlapping fragments HRla1 through HRla5 (Fig. 2B) (constructs $\Delta 16-\Delta 21)$. Whereas $\Delta 17$ and $\Delta 18$ gave full enhancer activity compared with control $\Delta 16$ (HR1a), $\Delta 19$ further enhanced activity by fivefold. Constructs $\Delta 20$ and $\Delta 21$ showed reduced activity. Interestingly, the HR1a3 sequence associated with very high enhancer activity contains several consensus binding sites for transcription factors known to be involved in Schwann or neural crest cell biology (Fig. 2C). These include binding sites for Sox, Snail, and cAMP response element-binding protein (CREB)/AP1 proteins, indicating a likely important role for these proteins in mediating the enhancer effect in differentiating Schwann cells.

\section{A $35 \mathrm{bp}$ core element is essential for} Oct6 activation in Schwann cells in vivo The activity of HR1a3 in combination with HR2 was tested in transgenic mice. Surprisingly, we found that HR1a3 has no activity in vivo (Fig. 3A) (construct 12). No Schwann cells were found to express LacZ in any of the 11 transgenics tested. Moreover, an additional construct that covers all of HR1a3 and extends to HR2 and 3' beyond the boundaries of HR2 (construct 11) also did not show activity in vivo. These results are in stark contrast with the activity of construct 10 , which contains 175 bp of extra sequence $5^{\prime}$ to HR1a3 (Fig. $1 B$ ), and demonstrate that an essential element is missing in constructs 11 and 12 .

To identify the missing element(s), we extended our phylogenetic analysis of the SCE to include the genomes of the opossum (a non-placental mammal) and the zebrafish. As is evident in Figure $3 B$, homology among the orthologous sequences rapidly breaks down when more distantly related species are included. Note that the threshold for the genomes of opossum and zebrafish has been lowered to $30 \%$. However, when we manually aligned the sequences abutted by the $5^{\prime}$ border of constructs 10 and 11 , one short element of $\sim 35$ bp was found strongly conserved in mammals and marsupials (Fig. $3 C$ ). We refer to this short conserved element as core 1 .

To test whether this $\mathrm{c} 1$ sequence represents an essential element of the SCE, we cloned the sequence in front of HR1a3 of construct 12 to generate construct 13. Indeed, this construct drives Schwann-cell-specific expression of the reporter in 9 of 18 transgenic mice (Fig. $3 A$ ), demonstrating that this short element contains genetic information that is essential for Schwann-cellspecific enhancer function in vivo. 
Temporal control of gene expression through the SCE is promoter independent

Previously, our experiments showing that the Oct6 SCE drives temporally correct expression of a reporter gene in the Schwann cell lineage, including its downregulation in fully differentiated cells, were performed with the Oct6 promoter driving reporter gene expression (Mandemakers et al., 2000). The use of the Oct6 promoter leaves open the possibility that the observed downregulation of the reporter gene was mediated through Oct6 promoter sequences and/or the SCE. Now, to test whether SCE construct 13 contains all the information to drive regulated expression and does so regardless of the linked promoter, transgenic lines (two lines for each construct) were generated in which the LacZ reporter is driven by the Oct6 promoter or the Hsp68 promoter. We choose one line for each construct with comparable copy number for additional analysis (Fig. 4A). LacZ reporter gene expression in the sciatic nerve of transgenic mice was monitored at different stages of development and compared with LacZ expression in nerves of mice carrying a LacZneo fusion ( $\beta$ geo) gene knocked in the Oct6 locus (Jaegle et al., 1996). As shown in Figure $4 B$, SCE construct 13 drives temporal expression from both the Oct6 and Hsp68 promoter in a pattern that primarily follows that of the endogenous Oct6 gene $\left(\right.$ Oct6 $\left.{ }^{\beta \text { geo }}\right)$. Both lines show upregulation of reporter gene expression at later stages of embryonic development (E16 to first day of postnatal life), and expression is downregulated after the first week of postnatal development and extinguished at later stages. However, expression of Hsp68LacZSCE13 is initiated slightly ahead of Oct6 ${ }^{\beta \text { geo }}$ but is extinguished correctly, whereas Oct6LacZSCE13 expression is initiated correctly but is extinguished with slower kinetics. Because we analyzed only one line for each construct, we do not know whether these marginal deviations in expression are caused by chromosomal integration position effects or whether they reflect differences between the Oct6 and Hsp68 promoter. Nevertheless, it is clear that SCE construct 13 contains all elements to respond to the transcription factor environment of differentiating Schwann cells and the signaling pathways that regulates their activities and that no Oct6 promoter-specific sequences are required for downregulating Oct6 expression in mature myelin-forming cells.

\section{Core element 1 contains an atypical dimeric binding site for Sox 10}

How does c1 contribute to Schwann-cell-specific enhancer function of the SCE? Using online bioinformatic tools, we identified potential binding sites within this $35 \mathrm{bp}$ sequence for several classes of transcription factors, including Sox proteins. Sox10, Sox2, Sox13, and Sox4 (Kuhlbrodt et al., 1998) (data not shown) are expressed in immature Schwann cells. Whereas all of these proteins bind to the consensus Sox binding site (A/T)(A/ $\mathrm{T}) \mathrm{CAA}(\mathrm{A} / \mathrm{T}) \mathrm{G}$, as found in element HR1a3, only Sox10 and Sox13 (data not shown) bind to the c1 element in EMSAs (Fig. $5 A$ ) (Harley et al., 1994). We examined the formation of protein-

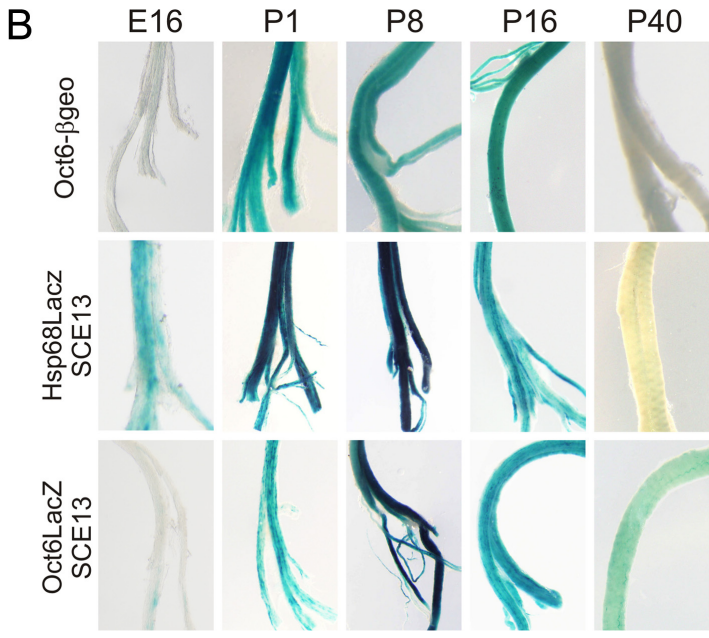

P40

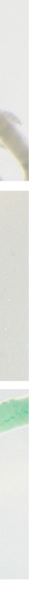

Figure 4. Developmental control of Schwann-cell-specific expression through SCE13. $\boldsymbol{A}$, Southern blot of genomic DNA of the two transgenic lines analyzed here shows that they carry a comparable number of transgenes. The transgene is detected with a probe that hybridizes to a $3.5 \mathrm{~kb}$ BamHI restriction fragment derived from the transgenic construct. The 0 ct6 locus is detected expression of $\beta$-galactosidase activity in nerves of the two transgenic lines was compared with the actosidase activity in 0ct6 $\beta$-galactosidase-neomycin (0ct6- $\beta$ geo) heterozygous knock-in animals (Jaegle et al., 1996;

DNA complexes on the $\mathrm{cl}$ probe using rat Schwannoma RT4D6P2T nuclear extracts and nuclear extracts of HEK293 cells transfected with a Sox10 expression cassette (Fig. 5A, Sox10). RT4-D6P2T cells resemble an early myelinating cell because it expresses considerable amounts of Oct6, Krox20, and Sox10 and low amounts of Mpz (Hai et al., 2002; Lindsley et al., 2007) (our unpublished observations) and thus provide an excellent model system to study promyelin-related transcription. Three major complexes were observed (Fig. $5 A$, indicated with asterisks), of which the slowest migrating complex contains Sox10 as evidenced by the additional decrease in electrophoretic mobility of this complex after addition of Sox10-specific antibodies (Fig. $5 A$ ). Interestingly, the Sox10-containing complex on the 1 probe has a lower mobility than the Sox 10 complex formed on the $\mathrm{c} 2$ probe (Fig. 5A), suggesting that Sox10 binds to $\mathrm{cl}$ as a homodimer or heterodimer. The sequence of the $\mathrm{c} 2$ probe (Fig. $5 E$ ) is derived from fragment HR1a3 and contains a consensus Sox binding site (Fig. 2C, underlined). Homodimeric binding of Sox 10 has been described before and depends on the presence of two closely spaced heptameric Sox binding sites in an inverted orientation (Peirano and Wegner, 2000). Examination of the $\mathrm{cl}$ sequence revealed the presence of a degenerate Sox binding site (AACTGAG) in opposite orientation and 4 bp spacing with the degenerate CACAAAC Sox binding site (Fig. 5E). To confirm that Sox 10 binds to $\mathrm{c} 1$ as a dimer, we performed EMSA (Fig. $5 B$ ) with nuclear extracts of HEK293 cells transfected with an expression construct encoding a truncated form of Sox10 (Sox10 MIC; amino acids 1-189 including the Sry-box). It has been shown before that this shorter form of Sox10 binds predominantly as a dimer on closely spaced inverted Sox binding sites such as present in the Mpz promoter (Fig. 5E, C/C') (Peirano and Wegner, 2000). Indeed, Sox10 MIC binds as a dimer to $\mathrm{c} 1$, and this binding is abolished when the $5^{\prime}$ Sox site is mutated $\left(\mathrm{cl}^{\mathrm{mut}}\right)$. Thus, the two degenerate Sox binding sites bind Sox10 strongly as a dimer, whereas the individual 3' Sox site has very little affinity for Sox10. 


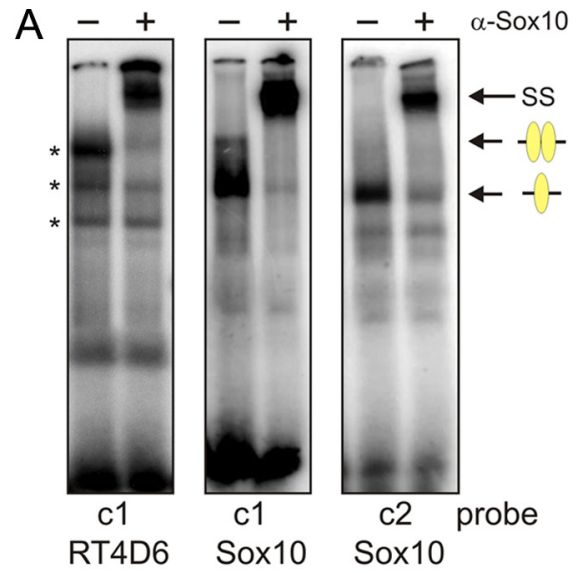

D

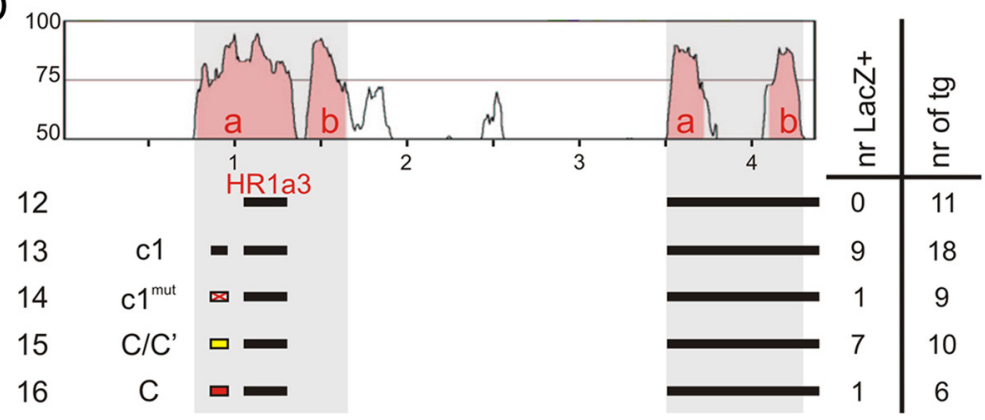

C

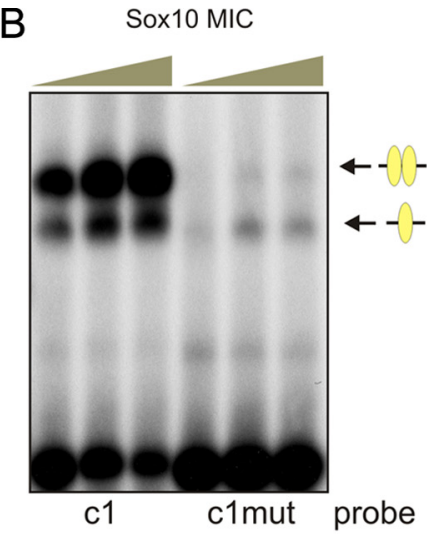

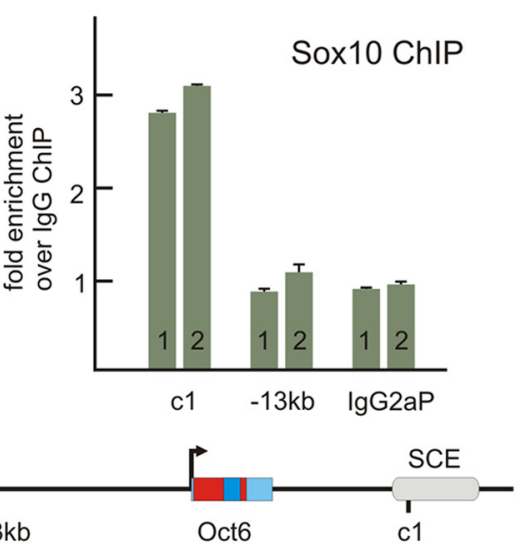

E

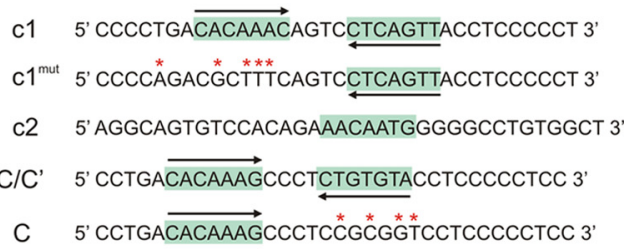

Sox binding concensus AACAAAG

Figure 5. Biochemical and functional analysis of core element c1. $\boldsymbol{A}$, EMSA with radiolabeled double-stranded oligonucleotides $\mathrm{C} 1$ and $\mathrm{c} 2$. The sequence of these probes is depicted in $\boldsymbol{E}$. Oligonucleotide probes were incubated with nuclear extracts from RT4-D6P2T cells or from HEK293 cells overexpressing Sox10 (labeled Sox10), in the presence (+) or absence ( - ) of Sox10 antibodies, as indicated. The three major DNA-protein complexes formed on c1 with RT4-D6P2T nuclear proteins are marked with an asterisk. The Sox10 monomeric and dimeric complexes are indicated with arrows. B, EMSA with radiolabeled double-stranded oligonucleotide $\mathrm{c} 1$ and $\mathrm{c}{ }^{\text {mut }}$. Oligonucleotide probes were incubated with increasing amounts of nuclear extracts from $\mathrm{HEK} 293$ cells expressing Sox10 MIC. C, ChIP of 0ct6 SCE sequences using Sox10 antibodies. Chromatin of RT4 -D6P2T cells was precipitated with Sox10 or rabbit IgG antibodies. The nonspecific rabbit IgG antibodies served as a control. Quantitative PCR on immune-precipitated and purified DNA using primers for the $\mathrm{c} 1 \mathrm{region}$ (c1), a region $13 \mathrm{~kb}$ upstream of the $0 \mathrm{ct} 6 \mathrm{promoter}$ (- $13 \mathrm{~kb}$ ), and a region associated with the lgG2a promoter (IgG2aP) was performed in triplicate and was used to determine the relative enrichment for these loci by Sox 10 over lgG immunoprecipitation. The experiment was performed twice. Data from both experiments are presented (1 and 2). D, Functional analysis of Sox binding sites in element c1. The in vivo activity of the various SCE constructs was assessed in newborn founder animals. The number of transgenic animals ( $\mathrm{nr}$ of $\mathrm{tg}$ ) and the number of animals that express LacZ in the peripheral nerves (nr LacZ ${ }^{+}$) is indicated. Constructs 14,15 , and 16 were created from construct 13 by replacing the $\mathrm{C} 1$ sequence for that of $\mathrm{c}{ }^{\text {mut }}, \mathrm{C} / \mathrm{C}^{\prime}$, and $\mathrm{C}$, respectively. $\boldsymbol{E}$, Sequence of $\mathrm{c} 1$ and related elements and its various mutant derivatives. Red asterisks indicate the nucleotides mutated in $\mathrm{C}^{\text {mut }}$. The position and orientation of the Sox 10 binding sites is indicated by green boxes and arrows. The $C / C^{\prime}$ and $C$ sequence is derived from the $M p z$ promoter (Peirano et al., 2000). Differences between C/ $C^{\prime}$ and C are indicated with red asterisks. The consensus Sox DNA binding motif was derived by Harley et al. (1994).

Next we examined whether indeed Sox 10 binds to the c1 SCE motif in chromatin of rat Schwannoma RT4-D6P2T cells. We performed ChIP using an antibody against Sox10 and control rabbit IgGs. We found c1 SCE sequences precipitated with threefold higher efficiency with Sox10 antibodies versus control IgG antibodies. Two control sequences, a $-13 \mathrm{~kb}$ sequence upstream of Oct6 and the IgG2a promoter, showed no enrichment for Sox10 and were precipitated with equal efficiency by Sox10 and IgG antibodies (Fig. 5C). Thus, Sox10 occupies c1 SCE chromatin in RT4-D6P2T cells.

To test whether this dimeric Sox10 binding contributes to SCE function in vivo, we generated a number of reporter constructs and tested their activity in transgenic animals. All these constructs are based on construct 12 and include HR1a3 and HR2. First, we tested whether mutation of the $5^{\prime}$ degenerate Sox site had any effect on the contribution of $\mathrm{c} 1$ to SCE activity. Mutating five nucleotides, including the particularly important central CAA motif as in $\mathrm{cl}^{\text {mut }}$ (Fig. $5 E$ ), results in loss of Sox10 binding (Fig. 5B). Replacing the $\mathrm{c} 1$ sequence in construct 13 for the $\mathrm{c} 1$ mut sequence, to generate construct 14 , results in a strong reduction of the number of transgenic mice expressing the LacZ reporter in Schwann cells of the sciatic nerve, from 9 of 18 to 1 of 9 (Fig. 5D). Thus, Sox10 binding to $\mathrm{c} 1$ is an essential component of the fully active SCE.
Because $\mathrm{cl}^{\text {mut }}$ completely abolishes Sox10 binding, we could not determine whether dimeric Sox10 binding per se, or perhaps monomeric Sox10 binding, would suffice for SCE function. To answer these questions, we tested two additional constructs. In the first construct tested, construct 15 , we replaced the $\mathrm{cl}$ sequence with that of the well documented C/C' dimeric Sox10 binding site from the $\mathrm{Mpz}$ promoter (Peirano and Wegner, 2000). In the second construct tested, construct 16, we replaced the $\mathrm{cl}$ sequence for the $\mathrm{C} / \mathrm{C}^{\prime}$ derivative $\mathrm{C}$, to which Sox10 binds exclusively as a monomer (sequence is shown in Fig. $5 E$ ). As is evident from the numbers presented in Figure $5 D$, the $\mathrm{Mpz}$ promoter-derived C/C' Sox binding site is as effective as the original c1 sequence in supporting Schwann-cell-specific expression (construct 15; 7 of 10). However, the monomeric Sox site C is not an effective substitute for $\mathrm{cl}$ (Fig. 5D) (construct 16; one of six). Thus, these experiments show that it is dimeric binding of Sox 10 to the $\mathrm{c} 1$ sequence and not just Sox 10 binding per se that provides an essential function in Schwann-cell-specific regulation through the Oct6 SCE.

\section{Discussion}

We have combined comparative genomics and transgenic analysis to identify regulatory regions within the Oct6 SCE that are required to drive Schwann-cell-specific expression in transgenic 
mice. We demonstrate that a 35 bp fragment called $\mathrm{cl}$ is an essential element of the SCE and contains two degenerate Sox protein binding sites in an inverted orientation. Sox10 protein binds to this element as a dimer, and we demonstrate that its in vivo activity critically depends on dimeric binding of Sox 10, because enhancer activity is lost in DNA mutants that bind Sox10 as a monomer. Thus, dimeric Sox10 binding provides a crucial function within the larger context of the Oct6 SCE, including HR1a and HR2, allowing the formation of a productive enhanceosome in response to developmental cues.

Phylogenetic comparison of genome sequences is a powerful tool to identify putative gene regulatory sequences. We initially analyzed human, mouse, and rat sequences of $\sim 50 \mathrm{~kb}$ surrounding the Oct6 gene and identified several conserved DNA elements surrounding the Oct6 structural gene (Fig. 1A). Within the boundaries of the SCE, two pairs of highly conserved blocks could be identified. Inclusion of non-placental mammals and fish in our analysis, however, shows that the high degree of homology is lost over larger evolutionary distances (Fig. 3). This rapid decline in overall sequence conservation down the phylogenetic ladder is remarkable and suggests that the core elements of the enhancer are relatively insensitive to the composition and sequence of the DNA in which they are embedded. In line with this observation, we found that the $35 \mathrm{bp} \mathrm{c1}$ could be lifted from its natural sequence context and placed directly in front of HR1a3 and HR2 to generate a functional enhancer (Fig. 3A).

HSS1 is associated with the promoter region of Oct6 and is embedded in a CpG island. Promoter proximal elements mediate interferon and dsRNA responses in fibroblasts, macrophages, and possibly Schwann cells through binding of the transcription factor Stat 1 (Hofmann et al., 2010). These elements fall within the limits of HSS1. Our analysis of transgenic founder animals carrying different SCE constructs did not reveal a role for promoter proximal sequences in directing Schwann-cell-specific expression. However, it did not rule out a possible contribution of these sequences to the temporal control of Oct6 gene expression, in particular downregulation in fully myelinating cells. Oct6 downregulation in myelinating Schwann cells is important because forced expression of Oct6 beyond the initial stages of myelination results in myelin degeneration and neuropathy (Ryu et al., 2007). It has been suggested that Oct6 gene expression is extinguished through an auto-inhibitory mechanism and/or through the action of Krox20 (Fig. 6), possibly through binding to the many potential Krox20 binding sites in the Oct6 promoter (Jaegle and Meijer, 1998; Zorick et al., 1999; Svaren and Meijer, 2008). Our results with SCE13-containing constructs, shown in Figure 4, demonstrate that the Oct6 promoter can be replaced by the minimal Hsp68 promoter. The downregulation of these constructs in mature nerves suggests that downregulation is mediated through the SCE and does not depend on Oct6 promoter-specific sequences. Whether Oct6 downregulation involves active repression by Krox 20 or other factors or loss of activation is an open question. Additional insight into the developmental downregulation of Oct6 will depend on the future identification of the relevant sequences within the SCE.

Our detailed mapping of HRla using a transient reporter Luciferase assay defines a 177 bp fragment HR1a3 that is highly active in differentiating rat Schwann cells. This element contains binding sites for a number of transcription factors that are expressed in Schwann cells, including Sox, Snail, CREB, and fos/jun proteins (Fig. 2). Of particular interest here is the CRE/AP1 binding site TGCGTCA, which has been shown to mediate cAMPinduced expression of dopamine $\beta$-hydroxylase (Swanson et al., 1998). Increased intracellular cAMP concentrations activate PKA, which in turn can activate a variety of proteins, including CREB and the p65 subunit of $\mathrm{Nf} \kappa \mathrm{B}$ (Tabernero et al., 1998; Yoon et al., 2008). A role for cAMP/PKA in Oct6 expression in Schwann cells was long suspected, but compelling evidence for such a role was obtained only recently. It was shown by Monk et al. (2009) that activation of Oct6 in zebrafish Schwann cells depends on the G-protein-coupled receptor Gpr126, a receptor hypothesized to signal through adenylyl cyclase. Indeed, pharmacological activation of adenylyl cyclase in Gpr126 mutant fish larvae activated Oct6 expression in Schwann cells and rescued the myelination defect in these mutant animals. Phosphorylation of CREB was also shown to result from Nrg1 signaling through the ErbB2 and ErbB3 heterodimeric receptor type tyrosine kinases, suggesting that both Gpr126 and ErbB2/ErbB3 signals contribute to regulated Oct6 gene transcription (Fig. 6) possibly through the CRE/AP1 element present in HR1a3.

However, whereas Luciferase reporter constructs carrying the HR1a3 and HR2 fragment were highly active in transient transfected rat Schwann cells, a LacZ reporter construct carrying the same enhancer fragments was inactive in transgenic mice (Figs. 2, 3). This discrepancy could reflect differences in Oct6 regulation in Schwann cells of different species. Indeed, it has been shown recently that mouse and rat Schwann cells exhibit different sensitivities to differentiation cues in vitro (Arthur-Farraj et al., 2011). Alternatively, the observed discrepancy reflects the fundamentally different nature of the two assays used here. In transfection assays, the DNA construct remains episomal, does not incorporate epigenetic marks, and is relatively open to the transcription factor environment of the nucleus. In contrast, a transgenic reporter construct is integrated in the chromosome, acquires epigenetic marks, and is subject to chromosomal position effects. Clearly, inclusion of the conserved $35 \mathrm{bp}$ fragment $\mathrm{c} 1$ (Figs. 3, 4) containing two inversely oriented heptameric Sox10 binding sites restored in vivo enhancer activity to the HR1a3 and HR2 DNA fragment and thus provides information that allows productive enhancer function in a chromatin context. Interestingly, two monomeric Sox 10 sites as in construct 16 (C and the $\mathrm{c} 2$ sequence embedded in HR1a3) (Fig. $5 D, E$ ) are no substitute for these inversely oriented sequences in $\mathrm{c} 1$ to which Sox10 binds as a dimer. Sequence-dependent dimerization is a property shared by all group E Sox proteins and depends on a short peptide se- 
quence in the $\mathrm{N}$-terminal portion of the proteins (Peirano and Wegner, 2000). The relevance of dimeric SoxE binding first became apparent when it was found that mutations in Sox9 that abolish dimeric binding but not monomeric binding cause a form of Campomelic dysplasia in humans (Sock et al., 2003). Likewise, mutation of the homologous sequence in mouse Sox10 $\left(\right.$ Sox $\left.10^{\text {aal/aal }}\right)$ results in loss of dimeric DNA binding, causing specific defects in neural crest-derived cell lineages. These include Schwann cells that are normally generated but fail to enter the promyelinating phase of differentiation and fail to activate Oct6 expression (Schlierf et al., 2002; Schreiner et al., 2007). Our demonstration here that the $\mathrm{cl}$ element is a target for dimeric Sox 10 binding and is essential for Oct6 activation provides a clear explanation for that observation.

How could dimeric Sox10 binding contribute to regulated expression of Oct6? A dimeric Sox10 protein binds DNA with higher affinity and induces stronger bending of the DNA helix than a monomeric Sox10 protein (Peirano and Wegner, 2000). Productive enhancer formation by dimeric Sox10 could result from the higher DNA binding affinity or, alternatively, DNA tethered Sox10 dimers assemble protein complexes different from those assembled by Sox 10 on monomeric sites. It is in principle possible that the differences in DNA topology induced by monomeric and dimeric Sox binding contribute to the latter. It is of note that, in Sox $10^{\text {aal/aal }}$ mice, Schwann cells are generated in normal numbers, whereas in the Sox10 null mice Schwann cells are not generated at all (Britsch et al., 2001; Schreiner et al., 2007). Because Sox $10^{\text {aal }}$ proteins can still bind as a monomer to Sox binding sites, this suggests that activity of a subset of Sox 10 target genes in the Schwann cell lineage depends on monomeric Sox10 binding, whereas another subset of genes including Oct6 depends on dimeric Sox10 binding. Furthermore, our transgenic data suggest that dimeric Sox 10 creates an open chromatin configuration in Schwann cells, allowing productive interactions of transcription factors with the Oct6 SCE. Regardless of whether this results from qualitative or quantitative differences between the two modes of Sox10 binding, the functional implications are profound.

Because Sox10 is expressed at high levels at all stages of Schwann cell differentiation, the dependency of the Oct6 SCE on Sox10 does not provide a ready explanation for the dynamic expression of Oct6 during Schwann cell differentiation. Most likely this information is encoded in HR1a3 or HR2. However, we cannot rule out the possibility that the activity of Sox 10 on the Oct6 SCE is regulated through modifications such as sumoylation (Taylor and Labonne, 2005; Girard and Goossens, 2006). Indeed, it has been shown that sumoylation of Sox 10 represses its capacity to activate specific promoters such as those of the Mitf and Gjb genes (Girard and Goossens, 2006).

It is expected that future identification of additional transcription factors interacting with regulatory elements within HR1a3 and HR2 will provide additional insight into the temporal regulation of Oct6 gene expression and myelin-related gene expression.

\section{References}

Arroyo EJ, Bermingham JR Jr, Rosenfeld MG, Scherer SS (1998) Promyelinating Schwann cells express Tst-1/SCIP/Oct-6. J Neurosci 18:7891-7902.

Arthur-Farraj P, Wanek K, Hantke J, Davis CM, Jayakar A, Parkinson DB, Mirsky R, Jessen KR (2011) Mouse schwann cells need both NRG1 and cyclic AMP to myelinate. Glia 59:720-733.

Bansal R, Pfeiffer SE (1987) Regulated galactolipid synthesis and cell surface expression in Schwann cell line D6P2T. J Neurochem 49:1902-1911.
Bejerano G, Pheasant M, Makunin I, Stephen S, Kent WJ, Mattick JS, Haussler D (2004) Ultraconserved elements in the human genome. Science 304:1321-1325.

Bermingham JR Jr, Scherer SS, O'Connell S, Arroyo E, Kalla KA, Powell FL, Rosenfeld MG (1996) Tst-1/Oct-6/SCIP regulates a unique step in peripheral myelination and is required for normal respiration. Genes Dev 10:1751-1762.

Britsch S, Goerich DE, Riethmacher D, Peirano RI, Rossner M, Nave KA, Birchmeier C, Wegner M (2001) The transcription factor Sox10 is a key regulator of peripheral glial development. Genes Dev 15:66-78.

Brockes JP, Fields KL, Raff MC (1979) Studies on cultured rat Schwann cells. I. Establishment of purified populations from cultures of peripheral nerve. Brain Res 165:105-118.

Dignam JD, Lebovitz RM, Roeder RG (1983) Accurate transcription initiation by RNA polymerase II in a soluble extract from isolated mammalian nuclei. Nucleic Acids Res 11:1475-1489.

Finzsch M, Schreiner S, Kichko T, Reeh P, Tamm ER, Bösl MR, Meijer D, Wegner M (2010) Sox10 is required for Schwann cell identity and progression beyond the immature Schwann cell stage. J Cell Biol 189:701-712.

Frazer KA, Pachter L, Poliakov A, Rubin EM, Dubchak I (2004) VISTA: computational tools for comparative genomics. Nucleic Acids Res 32:W273-W279.

Gandelman KY, Pfeiffer SE, Carson JH (1989) Cyclic AMP regulation of P0 glycoprotein and myelin basic protein gene expression in semi-differentiated peripheral neurinoma cell line D6P2T. Development 106:389-398.

Ghazvini M, Mandemakers W, Jaegle M, Piirsoo M, Driegen S, Koutsourakis M, Smit X, Grosveld F, Meijer D (2002) A cell type-specific allele of the POU gene Oct-6 reveals Schwann cell autonomous function in nerve development and regeneration. EMBO J 21:4612-4620.

Ghislain J, Charnay P (2006) Control of myelination in Schwann cells: a Krox 20 cis-regulatory element integrates Oct6, Brn2 and Sox 10 activities. EMBO Rep 7:52-58.

Girard M, Goossens M (2006) Sumoylation of the SOX10 transcription factor regulates its transcriptional activity. FEBS Lett 580:1635-1641.

Giresi PG, Lieb JD (2009) Isolation of active regulatory elements from eukaryotic chromatin using FAIRE (formaldehyde assisted isolation of regulatory elements). Methods 48:233-239.

Giresi PG, Kim J, McDaniell RM, Iyer VR, Lieb JD (2007) FAIRE (formaldehyde-assisted isolation of regulatory elements) isolates active regulatory elements from human chromatin. Genome Res 17:877-885.

Hai M, Muja N, DeVries GH, Quarles RH, Patel PI (2002) Comparative analysis of Schwann cell lines as model systems for myelin gene transcription studies. J Neurosci Res 69:497-508.

Harley VR, Lovell-Badge R, Goodfellow PN (1994) Definition of a consensus DNA binding site for SRY. Nucleic Acids Res 22:1500-1501.

He Y, Kim JY, Dupree J, Tewari A, Melendez-Vasquez C, Svaren J, Casaccia P (2010) Yyl as a molecular link between neuregulin and transcriptional modulation of peripheral myelination. Nat Neurosci 13:1472-1480.

Hofmann E, Reichart U, Gausterer C, Guelly C, Meijer D, Müller M, Strobl B (2010) Octamer-binding factor 6 (Oct-6/Pou3f1) is induced by interferon and contributes to dsRNA-mediated transcriptional responses. BMC Cell Biol 11:61.

Jaegle M, Meijer D (1998) Role of Oct-6 in Schwann cell differentiation. Microsc Res Tech 41:372-378.

Jaegle M, Mandemakers W, Broos L, Zwart R, Karis A, Visser P, Grosveld F, Meijer D (1996) The POU factor Oct-6 and Schwann cell differentiation. Science 273:507-510.

Jaegle M, Ghazvini M, Mandemakers W, Piirsoo M, Driegen S, Levavasseur F, Raghoenath S, Grosveld F, Meijer D (2003) The POU proteins Brn-2 and Oct-6 share important functions in Schwann cell development. Genes Dev 17:1380-1391.

Jang SW, Svaren J (2009) Induction of myelin protein zero by early growth response 2 through upstream and intragenic elements. J Biol Chem 284:20111-20120.

Jang SW, Srinivasan R, Jones EA, Sun G, Keles S, Krueger C, Chang LW, Nagarajan R, Svaren J (2010) Locus-wide identification of Egr2/Krox20 regulatory targets in myelin genes. J Neurochem 115:1409-1420.

Jessen KR, Mirsky R (2005) The origin and development of glial cells in peripheral nerves. Nat Rev Neurosci 6:671-682.

Kuhlbrodt K, Herbarth B, Sock E, Hermans-Borgmeyer I, Wegner M (1998) Sox10, a novel transcriptional modulator in glial cells. J Neurosci $18: 237-250$ 
Lindsley A, Snider P, Zhou H, Rogers R, Wang J, Olaopa M, KruzynskaFrejtag A, Koushik SV, Lilly B, Burch JB, Firulli AB, Conway SJ (2007) Identification and characterization of a novel Schwann and outflow tract endocardial cushion lineage-restricted periostin enhancer. Dev Biol 307:340-355.

Livak KJ, Schmittgen TD (2001) Analysis of relative gene expression data using real-time quantitative PCR and the $2(-$ Delta Delta $C(T))$ method. Methods 25:402-408.

Mandemakers W, Zwart R, Jaegle M, Walbeehm E, Visser P, Grosveld F, Meijer D (2000) A distal Schwann cell-specific enhancer mediates axonal regulation of the Oct-6 transcription factor during peripheral nerve development and regeneration. EMBO J 19:2992-3003.

Mathon NF, Malcolm DS, Harrisingh MC, Cheng L, Lloyd AC (2001) Lack of replicative senescence in normal rodent glia. Science 291:872-875.

Monk KR, Naylor SG, Glenn TD, Mercurio S, Perlin JR, Dominguez C, Moens CB, Talbot WS (2009) A G protein-coupled receptor is essential for Schwann cells to initiate myelination. Science 325:1402-1405.

Monuki ES, Weinmaster G, Kuhn R, Lemke G (1989) SCIP: a glial POU domain gene regulated by cyclic AMP. Neuron 3:783-793.

Morgan L, Jessen KR, Mirsky R (1991) The effects of cAMP on differentiation of cultured Schwann cells: progression from an early phenotype $(04+)$ to a myelin phenotype (P0+, GFAP-, N-CAM-, NGF-receptor-) depends on growth inhibition. J Cell Biol 112:457-467.

Peirano RI, Wegner M (2000) The glial transcription factor Sox10 binds to DNA both as monomer and dimer with different functional consequences. Nucleic Acids Res 28:3047-3055.

Peirano RI, Goerich DE, Riethmacher D, Wegner M (2000) Protein zero gene expression is regulated by the glial transcription factor Sox10. Mol Cell Biol 20:3198-3209.

Reiprich S, Kriesch J, Schreiner S, Wegner M (2010) Activation of Krox20 gene expression by Sox10 in myelinating Schwann cells. J Neurochem 112:744-754.

Renner K, Sock E, Bermingham JR Jr, Wegner M (1996) Expression of the gene for the POU domain transcription factor Tst-1/Oct6 is regulated by an estrogen-dependent enhancer. Nucleic Acids Res 24:4552-4557.

Ryu EJ, Wang JY, Le N, Baloh RH, Gustin JA, Schmidt RE, Milbrandt J (2007) Misexpression of Pou3f1 results in peripheral nerve hypomyelination and axonal loss. J Neurosci 27:11552-11559.

Sandelin A, Wasserman WW, Lenhard B (2004) ConSite: web-based prediction of regulatory elements using cross-species comparison. Nucleic Acids Res 32:W249-W252.

Schlierf B, Ludwig A, Klenovsek K, Wegner M (2002) Cooperative binding of Sox 10 to DNA: requirements and consequences. Nucleic Acids Res 30:5509-5516.
Schreiner S, Cossais F, Fischer K, Scholz S, Bösl MR, Holtmann B, Sendtner M, Wegner M (2007) Hypomorphic Sox10 alleles reveal novel protein functions and unravel developmental differences in glial lineages. Development 134:3271-3281.

Sock E, Pagon RA, Keymolen K, Lissens W, Wegner M, Scherer G (2003) Loss of DNA-dependent dimerization of the transcription factor SOX9 as a cause for campomelic dysplasia. Hum Mol Genet 12:1439-1447.

Spiegel I, Peles E (2009) A novel method for isolating Schwann cells using the extracellular domain of Necl1. J Neurosci Res 87:3288-3296.

Svaren J, Meijer D (2008) The molecular machinery of myelin gene transcription in Schwann cells. Glia 56:1541-1551.

Swanson DJ, Zellmer E, Lewis EJ (1998) AP1 proteins mediate the cAMP response of the dopamine beta-hydroxylase gene. J Biol Chem 273:24065-24074.

Tabernero A, Stewart HJS, Jessen KR, Mirsky R (1998) The neuron-glia signal beta neuregulin induces sustained CREB phosphorylation on Ser133 in cultured rat Schwann cells. Mol Cell Neurosci 10:309-322.

Taveggia C, Feltri ML, Wrabetz L (2010) Signals to promote myelin formation and repair. Nat Rev Neurol 6:276-287.

Taylor KM, Labonne C (2005) SoxE factors function equivalently during neural crest and inner ear development and their activity is regulated by SUMOylation. Dev Cell 9:593-603.

Topilko P, Schneider-Maunoury S, Levi G, Baron-Van Evercooren A, Chennoufi AB, Seitanidou T, Babinet C, Charnay P (1994) Krox-20 controls myelination in the peripheral nervous system. Nature 371:796-799.

van den Berg DL, Zhang W, Yates A, Engelen E, Takacs K, Bezstarosti K, Demmers J, Chambers I, Poot RA (2008) Estrogen-related receptor beta interacts with Oct4 to positively regulate Nanog gene expression. Mol Cell Biol 28:5986-5995.

Verheijen MH, Camargo N, Verdier V, Nadra K, de Preux Charles AS, Médard JJ, Luoma A, Crowther M, Inouye H, Shimano H, Chen S, Brouwers JF, Helms JB, Feltri ML, Wrabetz L, Kirschner D, Chrast R, Smit AB (2009) SCAP is required for timely and proper myelin membrane synthesis. Proc Natl Acad Sci U S A 106:21383-21388.

Yoon C, Korade Z, Carter BD (2008) Protein kinase A-induced phosphorylation of the $\mathrm{p} 65$ subunit of nuclear factor- $\kappa \mathrm{B}$ promotes Schwann cell differentiation into a myelinating phenotype. J Neurosci 28:3738-3746.

Zorick TS, Syroid DE, Arroyo E, Scherer SS, Lemke G (1996) The transcription factors SCIP and Krox-20 mark distinct stages and cell fates in Schwann cell differentiation. Mol Cell Neurosci 8:129-145.

Zorick TS, Syroid DE, Brown A, Gridley T, Lemke G (1999) Krox-20 controls SCIP expression, cell cycle exit and susceptibility to apoptosis in developing myelinating Schwann cells. Development 126:1397-1406. 